\title{
Genetic analysis of three maize husk traits by QTL mapping in a maize-teosinte population
}

\author{
Xiaolei Zhang ${ }^{1 \dagger}$, Ming Lu ${ }^{2 \dagger}$, Aiai Xia ${ }^{3}$, Tao Xu ${ }^{4}$, Zhenhai Cui ${ }^{5^{*}}$, Ruiying Zhang ${ }^{1^{*}}$, Wenguo Liu ${ }^{2^{*}}$ and Yan He ${ }^{3^{*}}$
}

\begin{abstract}
Background: The maize husk consists of numerous leafy layers and plays vital roles in protecting the ear from pathogen infection and dehydration. Teosinte, the wild ancestor of maize, has about three layers of small husk outer covering the ear. Although several quantitative trait loci (QTL) underlying husk morphology variation have been reported, the genetic basis of husk traits between teosinte and maize remains unclear.

Results: A linkage population including $191 \mathrm{BC}_{2} \mathrm{~F}_{8}$ inbred lines generated from the maize line Mo17 and the teosinte line X26-4 was used to identify QTL associated with three husk traits: i.e., husk length (HL), husk width $(\mathrm{HW})$ and the number of husk layers (HN). The best linear unbiased predictor (BLUP) depicted wide phenotypic variation and high heritability of all three traits. The HL exhibited greater correlation with HW than HN. A total of 4 QTLs were identified including 1, 1, 2, which are associated with HL, HW and HN, respectively. The proportion of phenotypic variation explained by these QTLs was 9.6, 8.9 and 8.1\% for HL, HN and HW, respectively.

Conclusions: The QTLs identified in this study will pave a path to explore candidate genes regulating husk growth and development, and benefit the molecular breeding program based on molecular marker-assisted selection to cultivate maize varieties with an ideal husk morphology.
\end{abstract}

Keywords: Maize, Teosinte, Husk, QTL

\section{Background}

Maize (Zea mays ssp. mays) is one of the most important cereal and forage crops worldwide. The most effective way for ensuring food supply is to improve maize yield [1]. As a leaf-like tissue covering outside of the ear,

\footnotetext{
*Correspondence: zhcui@syau.edu.cn; zhruiying@163.com;

liuwenguo168@163.com; yh352@cau.edu.cn

${ }^{t}$ Xiaolei Zhang and Ming Lu contributed equally to this work.

${ }^{5}$ College of Biological Science and Technology, Liaoning Province Research Center of Plant Genetic Engineering Technology, Shenyang Key Laboratory of Maize Genomic Selection Breeding, Shenyang Agricultural University, Shenyang 110866, China

'Quality and Safety Institute of Agricultural Products, Heilongjiang Academy of Agricultural Sciences, Harbin 150086, China

${ }^{2}$ Maize Research Institute, Jilin Academy of Agricultural Sciences, Gongzhuling 136100, China

${ }^{3}$ Sanya institute of China Agricultural University, Sanya 572025, China

Full list of author information is available at the end of the article
}

the husk plays important biological functions in warranting maize yield. Similar to foliar leaves, the husk can produce carbohydrates through photosynthesis process [2]. In addition, the husk nurseries and protects the ear from pathogen infection, birds and pests attack [3-5]. Moreover, the husk maintains appropriate moisture of kernel growth and prevents ear dehydration [6-14]. Therefore, the proper husk-related traits, i.e., HL, HW and NHL, serve as the critical factors influencing the rate of kernel dehydration after physiological maturity [2, 15-18].

Several recent studies have been conducted to understand the genetic basis of husk morphology $[9,13,14]$. The first QTL mapping about husk traits can be traced back to 2003 related to husk tightness [9]. In a $F_{2: 3}$ population, QTLs of husk tightness located on

(c) The Author(s). 2021 Open Access This article is licensed under a Creative Commons Attribution 4.0 International License, which permits use, sharing, adaptation, distribution and reproduction in any medium or format, as long as you give appropriate credit to the original author(s) and the source, provide a link to the Creative Commons licence, and indicate if changes were made. The images or other third party material in this article are included in the article's Creative Commons licence, unless indicated otherwise in a credit line to the material. If material is not included in the article's Creative Commons licence and your intended use is not permitted by statutory regulation or exceeds the permitted use, you will need to obtain permission directly from the copyright holder. To view a copy of this licence, visit http://creativecommons.org/licenses/by/4.0/ The Creative Commons Public Domain Dedication waiver (http://creativecommons.org/publicdomain/zero/1.0/) applies to the data made available in this article, unless otherwise stated in a credit line to the data. 
chromosome 1S, 1 L, $3 \mathrm{~L}$ and $7 \mathrm{~L}$ [9]. In 2016, the first genome wide association study (GWAS) for $\mathrm{NH}$ and husk weight were performed using $3 \mathrm{~K}$ SNP markers and identified a total of 24 and 29 SNPs associated with HN and husk weight, respectively [19]. At the same year, our group also performed GWAS using a larger scale of population with higher marker density (508 lines with 0.5 million of SNP markers) [13]. Under the stringent threshold $P<1.04 \times 10^{-5}$, nine variants significantly associated with HN, HW and HL were identified [13]. In 2018, the linkage mapping integrated with GWAS revealed five candidate genes related to HL and HN [14]. In 2020, utilizing denser marker (1.25 million) coupled with advanced statistical method, the other five candidate genes associated with HN and HT were detected [2]. Overall, these studies have unambiguously addressed that husk traits are complex and genetically controlled by multiple genes.

Teosinte (Zea mays ssp. parviglumis) is the wild progenitor of maize [20-22]. It exhibits significant resistance to cold [23, 24], drought [23], waterlogging [25, 26], pests [27] and diseases [27]. Maize-teosinte populations have been emerged as the ideal materials to identify important genes or QTLs related to multifaced maize traits. In addition, it is helpful to reveal the genetic mechanism of maize adapting to domestication and facilitate continued improvement of maize yield and quality [28-32]. In this study, we utilized a maizeteosinte population (MX) to analyze the genetic basis of three phenotypic husk traits, including HL, HN and HW. In addition, we positioned the large-effect QTL intervals using the bin map and predicted candidate genes associated with husk traits. A total of 4 QTLs were mapped out and 6 candidate genes were identified.

\section{Results}

\section{Phenotypic variation and heritability of husk traits}

The phenotypic variation and heritability of three husk traits in the parental line Mo17 and the recombinant inbred line (RIL) population in three environments were summarized in Table 1. Analyses of the best unbiased linear predictive (BLUP) values revealed that there was a broad range of phenotypic variation while the mean values were close to Mo17-parent value for all the three traits (Table 1). The three husk traits exhibited continuous and approximately normal distributions (Fig. 1). HL and HW were positively correlated, suggesting that the husk growth and development were coordinated in the aspects of length and width. The calculation of Broad-sense heritability revealed the high heritability for all the three husk traits $(0.91,0.86,0.86$ for HL, HN and HW, respectively) (Table 1), indicating that the majority of husk phenotypic variations are controlled by genetic factors and suitable for further QTL mapping analysis.

\section{Identification of QTLs for three husk traits}

With the ultra-high-density linkage maps, a total of four QTLs were identified after 1000 permutations with an empirical logarithm of the odds (LOD) threshold of 3.5, 4.0 and 3.5 for HL, HN and HW, respectively (Table 2 and Fig. 2). The average of QTL intervals was $6.0 \mathrm{Mb}$ with a range of 5.1-8.9 Mb. For HL, one QTL (qHL-1-1) was detected on chromosome 1 and the phenotypic variation explained by this QTL was 9.6\%. For HN, a total of two QTLs (qHN-1-1 and qHN-1-2) were identified on chromosome 1 and the phenotypic variation explained by each individual QTL was $8.9 \%$, respectively. For HW, one QTL (qHW-3-1) was identified on chromosome 3 and explained $8.1 \%$ of phenotypic variation. All the four QTLs explained less than 10\% of phenotypic variation, indicating that $\mathrm{HL}, \mathrm{HN}$ and $\mathrm{HW}$ are controlled by multiple small-effect QTLs in this $\mathrm{BC}_{2} \mathrm{~F}_{8}$ teosinte-maize population.

\section{Genetic overlap of QTL in MX and other RIL populations}

To assess the genetic overlap related to different husk traits, a 1.5-LOD support interval of QTL for HL, HW, and $\mathrm{HN}$ in MX population and the other three RIL populations [14] were compared (Fig. 3). This analysis revealed a minimal number of overlap with only qHL-1-1 and qHN-1-2 with a HW QTL in BYK population. These results suggest that genetic loci controlling husk traits in the MX population may largely differ from the other RIL populations.

\section{Identification of candidate genes and the corresponding tissue-specific expression pattern}

To explore the candidate genes underlying husk traits, four QTLs were further narrowed by bin map analysis

Table 1 Variance composition and broad-sense heritability for $191 \mathrm{BC}_{2} \mathrm{~F}_{8}$ families in three environments

\begin{tabular}{|c|c|c|c|c|c|c|c|}
\hline \multirow[t]{2}{*}{ Traits } & \multirow[t]{2}{*}{ Mo17 } & \multicolumn{2}{|l|}{ RILs } & \multicolumn{3}{|l|}{ Mean square } & \multirow[t]{2}{*}{ Heritability $^{b}$} \\
\hline & & Means \pm SD & Range & Environment (E) & Genotype (G) & $G \times E^{a}$ & \\
\hline $\mathrm{HL}$ & $21.52 \pm 1.88$ & $23.49 \pm 2.28$ & $17.39-29.80$ & $757.86^{* *}$ & $37.24^{* *}$ & $3.45^{* *}$ & 0.91 \\
\hline NN & $9.24 \pm 1.92$ & $7.89 \pm 0.78$ & $4.80-10.36$ & $5.41^{* *}$ & $2.22^{* *}$ & 0.31 & 0.86 \\
\hline HW & $7.52 \pm 1.00$ & $7.49 \pm 0.53$ & $6.22-9.26$ & $40.19^{* *}$ & $4.89 * *$ & $0.7^{* *}$ & 0.86 \\
\hline
\end{tabular}

${ }^{\mathrm{a}} \mathrm{G} \times \mathrm{E}$ designates the interaction between $\mathrm{G}$ and $\mathrm{E} ;{ }^{\mathrm{b}}$ Broad-sense heritability. ${ }^{*} P \leq 0.05,{ }^{*} P \leq 0.01$ 


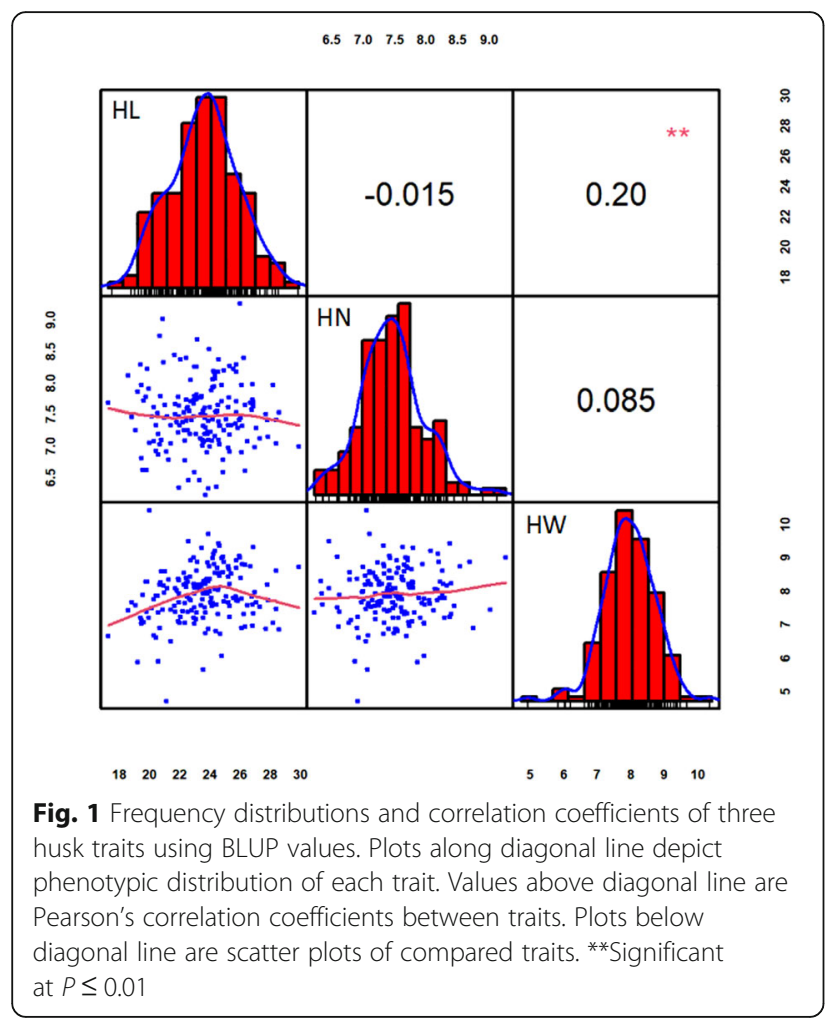

(Fig. 4). The physical distance of peak bins ranged from $0.54 \mathrm{Mb}-2.72 \mathrm{Mb}$ (Table 3). According to the annotation in the MaizeGDB database (www.maizegdb.org), a total of 10, 58, 62 and 16 protein-coding genes were identified within peak bin for qHL-1-1, qHN-1-1, qHN1-2 and qHW-3-1, respectively. Next, the in-silico expression pattern analysis was performed using RNA-seq data collected from husk and other nine different tissues, which are published available in an online comparative RNA-seq expression platform (https://qteller.maizegdb. org) (Fig. 5). Judged from the specific and high expression in husk, a total of six candidate genes with annotated function were identified, including 1, 2, 2 and 1 for HL-1-1, HN-1-1, HN-1-2 and HW-3-1, respectively.

\section{Discussion}

Genetic basis of husk traits in the MX population

All the three husk traits in the MX population exhibited a broad range of phenotypic variation with normal distribution. The genetic analysis showed that the heritability of three husk traits is fairly high, indicative of superior genetic effect in this population studied [33]. In addition, except for environment variation, none of significant difference were detected in genetic or interaction between genetic and environment within RILs. Considering this population was conducted by twice back-cross with Mo17, the high consistency of linkage maps among RILs may result in the genetic similarity among MX RILs [34]. Moreover, significantly positive correlation was observed between HL and HW, indicating that the growth and development of husk is coordinated in the dimension of length and width. By comparison, $\mathrm{HN}$ was not correlated with $\mathrm{HL}$ or HW, suggesting that the molecular pathways regulating the numerous initiations of husk layer may be independent from husk growth.

The husk traits were regulated by one, two and one QTL with small-effects (8.1-9.6\%), indicating that each of three husk traits is polygenic and controlled by multiple genes with small effects in the MX population. Interestingly, when compared four QTLs of husk traits in MX with QTLs identified previously in other maize linkage populations [14], we did not detect any overlap of QTLs for the same trait. This result implies that the genetic basis of husk morphology in the MX population is kind of unique compared to other maize linkage population, highlighting the power of the MX population to interpret the genetic variation, which may be never accomplished in the regular modern maize population.

\section{Candidate genes underlying husk QTLs}

To successfully obtain candidate genes, fine-mapping is considered as the general strategy in QTL study. However, it often takes long period for back-cross to get near

Table 2 Individual QTL for husk traits in the MX BC${ }_{2} F_{8}$ population

\begin{tabular}{|c|c|c|c|c|c|c|c|c|c|}
\hline Traits & QTL & Environments & Chromosome & $\begin{array}{l}\text { Peak } \\
\text { (cM) }^{\mathrm{a}}\end{array}$ & $\begin{array}{l}\text { Physical Position } \\
(\mathrm{Mb})^{\mathbf{b}}\end{array}$ & $\begin{array}{l}\text { Genetic interval } \\
\text { (cM) }\end{array}$ & $\begin{array}{l}\text { Additive } \\
\text { effect }^{c}\end{array}$ & $\begin{array}{l}\text { LOD } \\
\text { value }\end{array}$ & $\begin{array}{l}\text { Phenotypic } \\
\text { variation } \%^{\mathrm{d}}\end{array}$ \\
\hline$\overline{\mathrm{HL}}$ & $\begin{array}{l}\mathrm{qHL}-1- \\
1\end{array}$ & $\mathrm{LN}$ & 1 & 97.7 & $198.5-203.7$ & $93.2-98.2$ & 1.59 & 4.36 & 9.6 \\
\hline \multirow[t]{2}{*}{$\mathrm{HN}$} & $\begin{array}{l}\mathrm{qHN}- \\
1-1\end{array}$ & BJ & 1 & 28.1 & $7.72-16.6$ & $22.8-31.7$ & -0.25 & 4.24 & 8.9 \\
\hline & $\begin{array}{l}\mathrm{qHN}- \\
1-2\end{array}$ & BLUP & 1 & 130.4 & $275.0-280.1$ & $126.2-131.9$ & 0.29 & 4.50 & 8.9 \\
\hline HW & $\begin{array}{l}\text { qHW- } \\
3-1\end{array}$ & NM & 3 & 179.1 & $204.6-209.8$ & $173.7-183.4$ & 0.30 & 3.76 & 8.1 \\
\hline
\end{tabular}

${ }^{\mathrm{a}}$ Genetic position in centimorgans (cM) of QTL with the highest LOD; ${ }^{\mathrm{b}}$ Physical position of QTL based on the B73 reference sequence (v2); ${ }^{\mathrm{C} A d d i t i v e ~ e f f e c t ~ o f ~ Q T L: ~}$ a positive value means the allele from the parent Mo17 increases the index of traits, whereas a negative value indicates that the allele from teosinte decrease the index of traits; ${ }^{d}$ Percentage of the phenotypic variation explained by the additive effect of QTL 

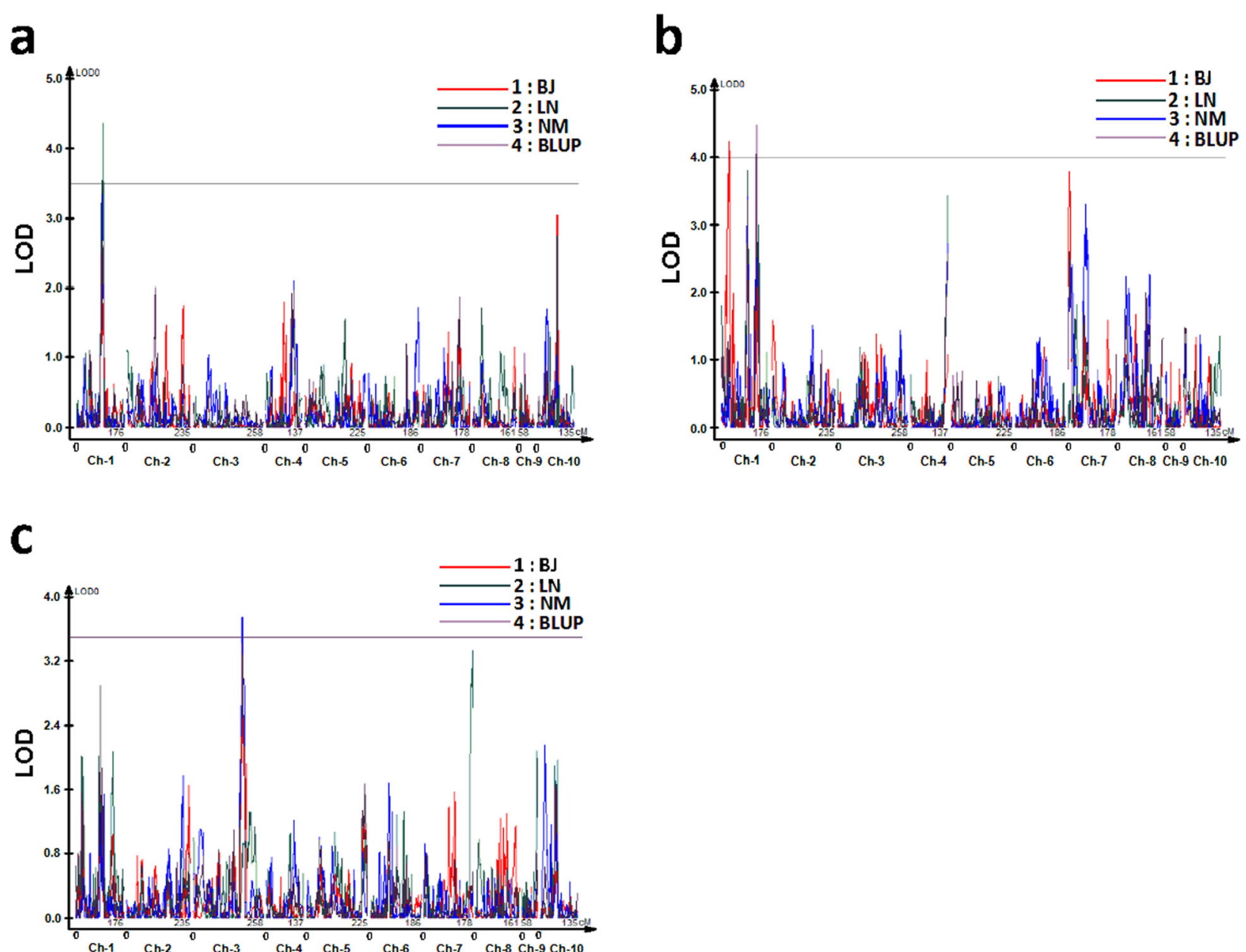

Fig. 2 LOD profiles of QTL for three husk traits identified in different environments: a HL; b HN; c HW. BJ, Beijing; NM, Neimeng; LN, Liaoning; BLUP, best linear unbiased prediction

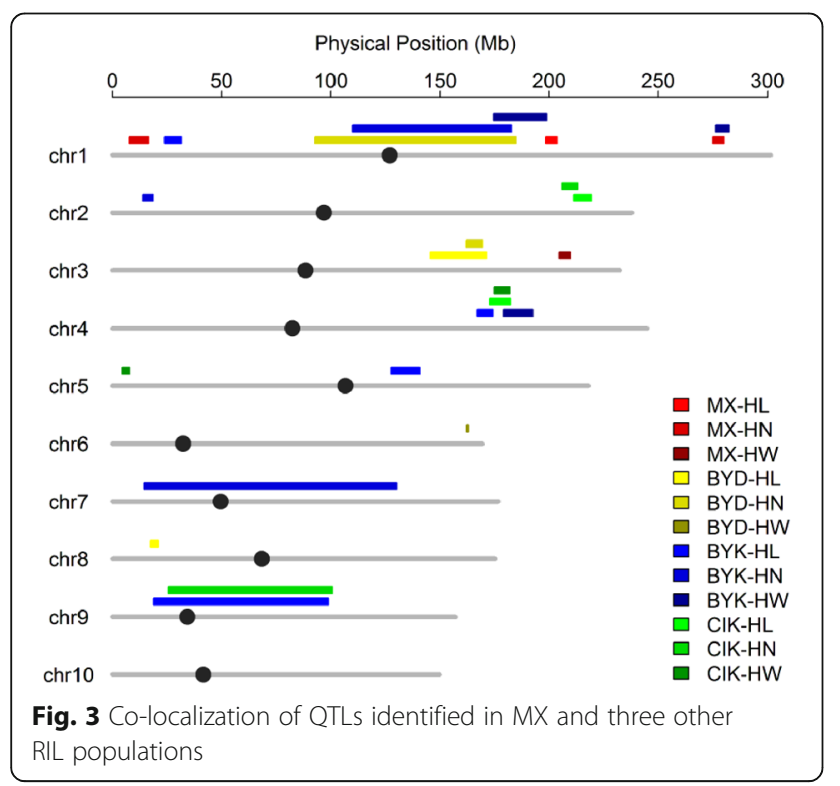

isogenic lines (NIL) lines. Bin map is an alternative strategy to fine-mapping the yield-associated loci applied in sorghum [35], rice [36], and maize [2, 13, 14, 18]. In this study, four husk related QTLs were narrowed from the original $5.1 \mathrm{Mb}-8.9 \mathrm{Mb}$ interval to $0.54 \mathrm{Mb}-2.72 \mathrm{Mb}$ region according to a bin map. Within four peak bin intervals, there are a total of 102 putative protein-coding genes. By retrieving tissue-specific expression pattern, we could identify six candidate genes with known molecular function and highly expressed in husk. For qHL$1-1$, the only candidate gene was GRMZM2G106928, which encodes Copper/zinc superoxide dismutase 2 $(\mathrm{Cu} / \mathrm{Zn}$ SOD2) involving in the photosynthetic antioxidant system [37]. If this gene could be proved by the future functional study, it will provide evident that the photosynthesis may play a role in regulating husk development alike the foliar leaves. For qHN-1-1, two candidate genes GRMZM2G162749 and GRMZM2G034302 were identified, which encode Cycling DOF factor 1 (CDF1) and Sucrose transporter 2 (SUC2), respectively. 
a

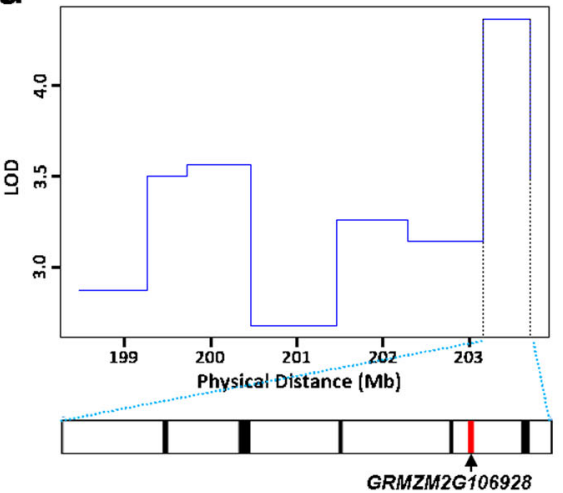

C

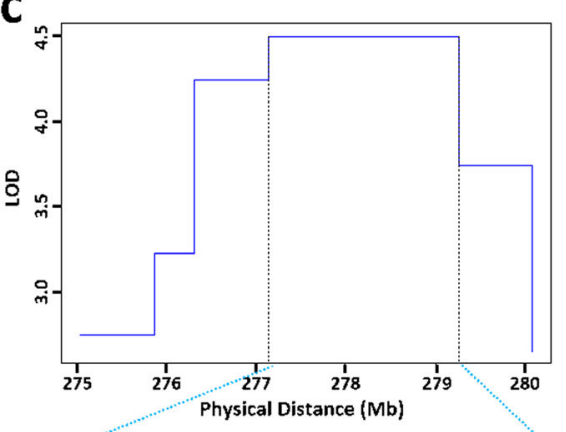

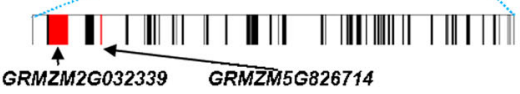

b

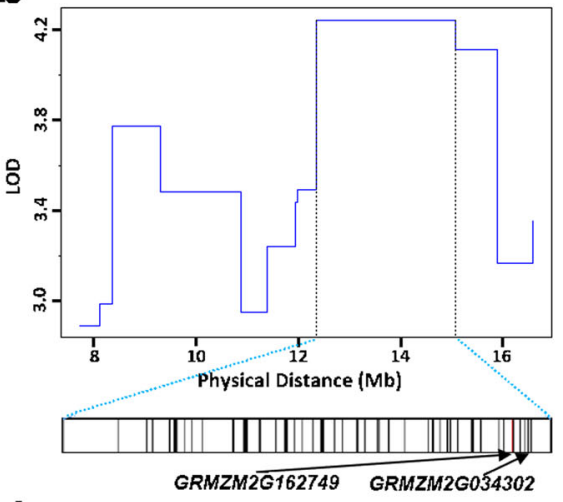

d

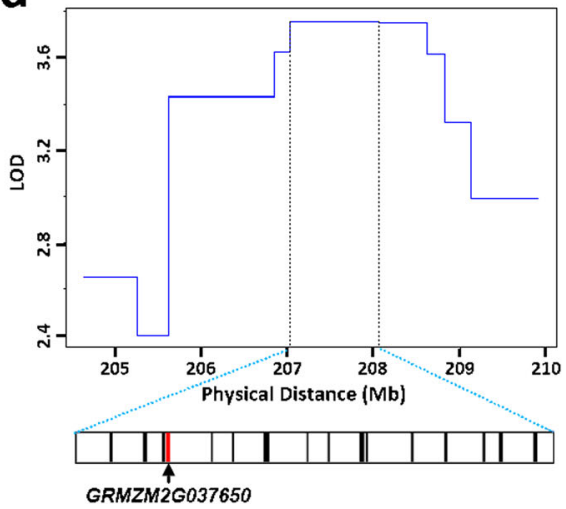

Fig. 4 LOD profiles for QTL recombination breakpoints and candidate genes located in the peak points: a qHL-1-1; b qHN-1-1; c qHN-1-2; d qHW-3-1. The candidate genes are indicated by red bands and other genes are indicated by gray bands

It has reported in Arabidopsis that Cycling DOF factors are essential for a photoperiodic flowering response [38]. In our previous study, maize flowering time showed significantly positively correlated with HN [13]. In this scenario, it is likely that the maize CDF1 could control HN via mediating the flowering time. It is well known that SUC2 functions in transporting the sucrose into phloem vascular in crops [39]. Therefore, it is likely that sucrose transported by SUC2 plays a role in husk development. For qHN-1-2, two candidate genes GRMZM2G032339 and GRMZM5G826714 were identified, which encode a MADS-box transcription factor and a COBRA-like extracellular glycosyl-phosphatidyl inositol-anchored protein, respectively. It has been reported that the MADS-box transcription factor plays a key role in plant flowering time and node number development [40, 41].

Table 3 Candidate genes within the genomic region spanning the single bin

\begin{tabular}{|c|c|c|c|c|c|c|}
\hline$\overline{\mathrm{QTL}}$ & Chr & Bin & $\begin{array}{l}\text { Bin length } \\
\text { (bp) }\end{array}$ & ID & Position $^{a}$ & Annotation $^{\mathbf{b}}$ \\
\hline $\begin{array}{l}\mathrm{qHL}-1- \\
1\end{array}$ & 1 & $\begin{array}{l}\text { PZE- } \\
101160628\end{array}$ & 548,905 & GRMZM2G106928 & $\begin{array}{l}\text { 203,625, } \\
515.203631858\end{array}$ & Copper/zinc superoxide dismutase 2 \\
\hline \multirow[t]{2}{*}{$\begin{array}{l}\mathrm{qHN}-1- \\
1\end{array}$} & 1 & $\begin{array}{l}\text { PZE- } \\
101021308\end{array}$ & $2,719,182$ & GRMZM2G162749 & $\begin{array}{l}14,848 \\
652 . .14854535\end{array}$ & Cycling DOF factor 1 \\
\hline & & & & GRMZM2G034302 & $\begin{array}{l}\text { 15,067, } \\
584 . .15075973\end{array}$ & Sucrose transporter 2 \\
\hline \multirow[t]{2}{*}{$\begin{array}{l}\mathrm{qHN}-1- \\
2\end{array}$} & 1 & SYN9147 & $2,128,406$ & GRMZM2G032339 & $\begin{array}{l}277,216 \\
651 . .277300425\end{array}$ & K-box region and MADS-box transcription factor family protein \\
\hline & & & & GRMZM5G826714 & $\begin{array}{l}277,445 \\
149 . .277451612\end{array}$ & $\begin{array}{l}\text { COBRA-like extracellular glycosyl-phosphatidyl inositol-anchored } \\
\text { protein family }\end{array}$ \\
\hline $\begin{array}{l}\text { qHW- } \\
3-1\end{array}$ & 3 & $\begin{array}{l}\text { PZE- } \\
103154161\end{array}$ & $1,040,297$ & GRMZM2G037650 & $\begin{array}{l}\text { 207,219, } \\
415 . .207228119\end{array}$ & Myb domain protein 42 \\
\hline
\end{tabular}

\footnotetext{
${ }^{a}$ Gene position according to the B73 reference sequence (V2); ${ }^{b}$ Gene annotated according to their homologous gene in Arabidopsis thaliana or rice
} 


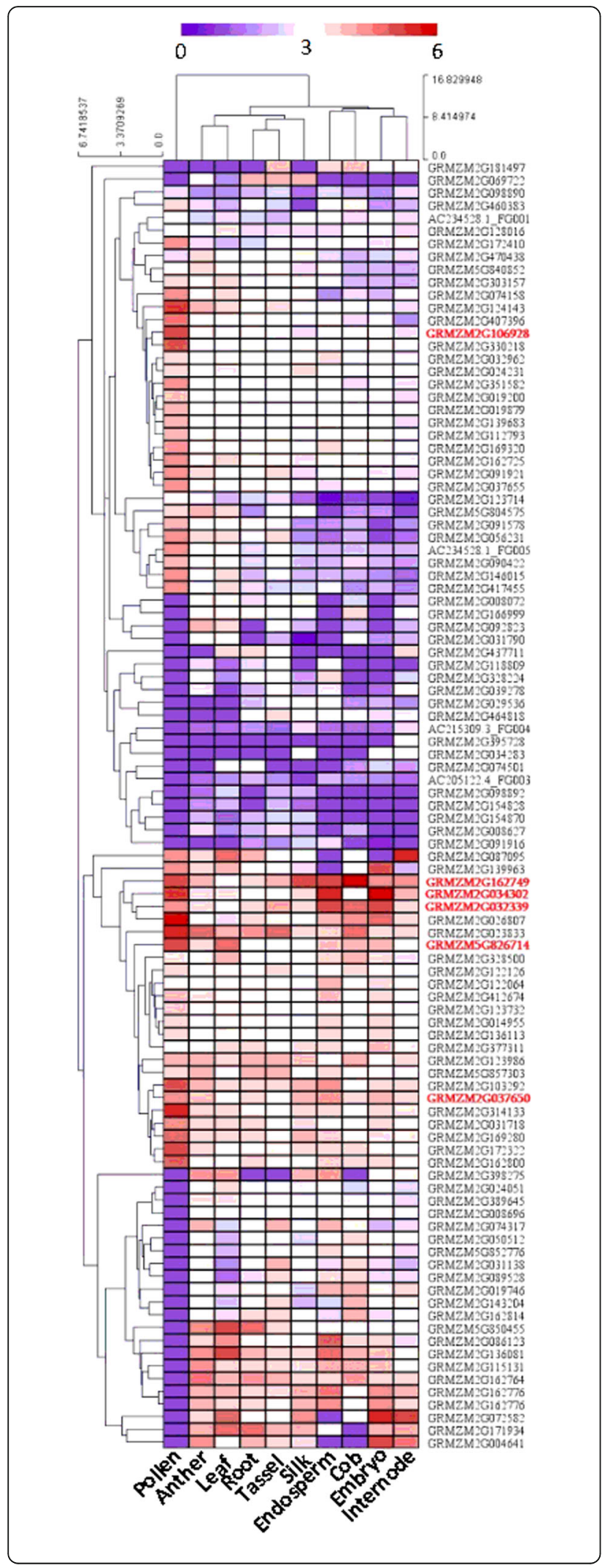

Fig. 5 Heat-map showing tissue-specific expression patterns of protein-coding genes within QTL. The $\log _{10}$-transformed ratios of normalized RNA-seq counts in husk relative to other tissues as indicated at the bottom of each column. Columns and rows are ordered according to hierarchical cluster analysis at the top and left. The red, white, and blue represent higher, similar or lower expression in husk relative to other tissues, respectively

Therefore, this MADS-box transcription factor may also regulate $\mathrm{HN}$ through mediating maize flowering time. COBRA-family proteins have been documented as regulators of cellulose biogenesis [42], and act as essential factors in anisotropic expansion via cellulose microfibril orientation of plant morphogenesis [43]. As HN is determined by inner husk organ elongation related to anisotropic expansion, it is conceivable that COBRA-family proteins are involved in the formation of husk. For qHW-3-1, the only candidate gene GRMZM2G037650 encodes a Myb-family transcription factor, which is known to participate in multifaced molecular pathways through regulating down-stream gene expression.

\section{Importance of QTLs relevant to husk traits in maize genetic and breeding}

As the wild ancestor of maize, teosinte exhibits many advantages relative to modern maize, such as significant resistance to biotic or abiotic stresses [23-27]. However, during the maize domestication, hundreds of genes lost. In this context, recovering and utilizing teosinte genes became a promising strategy to further improve modern maize satisfying the requirement of varieties growing in different area. Indeed, a recent study has demonstrated that introgressing the wild UPA2 allele originated from teosinte into modern hybrids could reduce leaf angle, leading to the enhanced yield under high-density condition [44]. The heavy coverage of maize husk offers nursery and healthy environment safeguarding the early stage of ear growth and development. However, it may turn into the major barrier against kernel dehydration after physiological maturation of maize, challenging the mechanical harvest of corn production. Till now, none of genes specially regulating husk development have been identified, raising a critical issue that we do not have any objective to fulfil gene editing. Therefore, the husk-relevant QTLs offers prospective routes to modify husk morphology through molecular marker-assisted selection in maize breeding program.

\section{Conclusion}

In this work, we describe the interpretation of the genetic basis and QTL mapping of three husk traits in a teosinte-maize population. A total of four QTLs underlying husk length and width as well as the number of husk layer were identified. Importantly, all four QTLs 
were not overlapped with other husk-relevant QTLs identified in the previous population. Therefore, the newly-identified QTLs in this study will greatly enlarge genomic targets to explore candidate genes regulating husk growth and development, and benefit the breeding program based on molecular marker-assisted selection to pursue new varieties with proper husk morphology.

\section{Methods}

\section{Plant materials and phenotyping}

The maize-teosinte (Mo17/X26-4, MX) RIL population including 191 families was derived from crossing between Mo17 and one teosinte line (Teo X26-4, accession number PI 566686). The $\mathrm{F}_{1}$ individual was backcrossed with Mo17 twice and then self-pollinated for eight generations lead to the construction of the maize-teosinte introgression $\mathrm{BC}_{2} \mathrm{~F}_{8}$ population. It is noted that both of parent lines, Mo17 and teosinte were originally obtained from the maize stock center (http:// maizecoop.cropsci.uiuc.edu/), and the detailed information about the development of the MX population has been described in two previous studies [34, 45]. The MX population was planted in a randomized complete block design at three different regions including Beijing (BJ, $\left.40^{\circ} 08^{\prime} \mathrm{N}, 116^{\circ} 10^{\prime} \mathrm{E}\right)$, Neimeng (NM, 4031' $\left.\mathrm{N}, 107^{\circ} 05^{\prime} \mathrm{E}\right)$, and Liaoning (LN, 40 ${ }^{\circ} 82^{\prime} \mathrm{N}, 123^{\circ} 56^{\prime} \mathrm{E}$ ) in 2015 and 2016. Each line was grown in a single-row plot with a row length of $250 \mathrm{~cm}$ and $60 \mathrm{~cm}$ between rows under natural field conditions. The details about husk trait measurement were described previously [13]. We declare that all the collections of plant and seed specimens related to this study were performed in accordance with the relevant guidelines and regulations by Ministry of Agriculture (MOA) of the People's Republic of China.

\section{Analysis of phenotypic data}

The phenotypic variation of husk traits was analyzed using $\mathrm{R}$ software 4.0.1 with the "aov" function (ANOVA). The model for the ANOVA was $y=+i+j+$, where $i$ is the effect of ith genotype, $j$ is the effect of the jth environment with error. The broad-sense heritability of husk traits was calculated as: $\mathrm{h} 2=\mathrm{G} 2 /(\mathrm{G} 2+\mathrm{GE} 2 / \mathrm{n}+$ $2 / n$ ) [46], where G2 is genetic variance, GE2 is the interaction of genotype with environment, 2 is the resident error and $\mathrm{n}$ is the number of the environments. The BLUP value was calculated using a linear mixed model. Both genotype and environment were treated as random effects in the R function "Ime4".

\section{Genotyping and constructing the bin map}

The genotype of the MX population was obtained by utilizing the Illumina MaizeSNP50 array (Illumina Inc., San Diego, CA, USA) [47], containing 56,110 SNPs. Quality control was performed by removing monomorphic markers $(\mathrm{MAF}<5 \%)$ with a missing rate higher than $10 \%$ by PLINK software [48]. Finally, 12,390 high-quality SNPs were selected to build the genetic linkage map with CarthaGene software [49] using Perl scripts in a Linux system (www.maizego.org/Resources. html). The details about the construction of genetic linkage maps has been described previously [34]. The cosegregating markers were merged into a bin. With the logarithm of the odds (LOD) of each bin marker, a bin map could be drawn following the physical position of bin marker.

\section{QTL mapping}

The QTLs were analyzed by composite interval mapping method implemented in Windows QTL Cartographer 2.5 [50]. Genome was scanned at every $1.0 \mathrm{cM}$ interval between markers using a $10 \mathrm{cM}$ window size. A forward and backward stepwise regression with five controlling markers was conducted to control background from flanking markers. The LOD threshold was determined by the 1000 permutations at a significance $(P<0.05)$ and used to identify the significant QTL [51]. With the 1.5LOD support interval method, the confidence interval for each QTL position was estimated [52].

\section{Gene annotation}

QTLs were delimited to a single peak bin interval based on bin map. The protein-coding genes within intervals were listed according to MaizeGDB database (V2). Each of the corresponding gene were annotated by performing BLASTP searches at the NCBI (blast.ncbi.nlm.nih.gov/ Blast.cgi).

\section{Tissue-specific expression pattern of candidate genes}

RNA-seq dataset from husk were downloaded from NCBI's Sequence Read Archive (SRA) database. The quality of RNA-seq reads were controlled by FastQC software. Sequence reads were aligned to B73 RefGen v2 by the TopHat (v2.1.0) pipeline with a built-in Bowtie (v0.12.9) program. Unique-mapped reads were retained for counting FPKM. All the RNA-seq datasets from other nine tissues were obtained by qTeller RNA-seq expression platform (https://qteller.maizegdb.org). Then the FPKM was calculated to TPM by the model:

$$
T P M i=\left(\frac{F P K M}{\sum_{j} F P K M j}\right) \times 10^{6}
$$

Values used in heat-map plot were the $\log _{10}$-transformed ratios of normalized TPM counts in husk relative to other tissues. 


\section{Acknowledgments}

We thank all members of our laboratories for helpful discussion and assistance during this research.

\section{Authors' contributions}

$\mathrm{YH}$ and $\mathrm{WL}$ conceived the study. YH designed the experiments. ML and TX performed the experiments. ZC and AX analyzed the results. XZ wrote the manuscript. YH and RZ provided scientific suggestions and revised the manuscript. All authors have read and agreed to the published version of the manuscript. Both authors read and approved the final manuscript.

\section{Funding}

This research was funded by the Key Laboratory Biology and Genetic Improvement of Maize in Northeast Region, Ministry of Agriculture, China, grant number CXGC2018KFKT001.

\section{Availability of data and materials}

Genotyping and sequencing data from this study can be found in the GenBank database under accession number MN026742-MN026862.

\section{Declarations}

\section{Ethics approval and consent to participate}

Not applicable.

\section{Consent for publication}

Not applicable.

\section{Competing interests}

The authors declare that they have no conflicts of interest.

\section{Author details}

${ }^{1}$ Quality and Safety Institute of Agricultural Products, Heilongjiang Academy of Agricultural Sciences, Harbin 150086, China. ${ }^{2}$ Maize Research Institute, Jilin Academy of Agricultural Sciences, Gongzhuling 136100, China. ${ }^{3}$ Sanya institute of China Agricultural University, Sanya 572025, China. ${ }^{4}$ Tieling Academy of Agricultural Sciences, Tieling 112000, China. ${ }^{5}$ College of Biological Science and Technology, Liaoning Province Research Center of Plant Genetic Engineering Technology, Shenyang Key Laboratory of Maize Genomic Selection Breeding, Shenyang Agricultural University, Shenyang 110866, China.

Received: 2 April 2021 Accepted: 12 May 2021

Published online: 26 May 2021

\section{References}

1. Duvick DN. Genetic progress in yield of United States maize (Zea mays L.). Maydica. 2005;50(3):193-202.

2. Cui ZH, Dong HX, Zhang A, Ruan YY, Jiang SQ, He Y, et al. Denser markers and advanced statistical method identified more genetic loci associated with husk traits in maize. Sci Rep. 2020;10(1):8165. https://doi.org/10.1038/ s41598-020-65164-0.

3. Barry D, Lillehoj EB, Widstrom NW, McMillan WW, Zuber MS, Kwolek WF, et al. Effect of husk tightness and insect (Lepidoptera) infestation on aflatoxin contamination of preharvest maize. Environ Entomol. 1986;15(6): 1116-8. https://doi.org/10.1093/ee/15.6.1116.

4. Warfield C. Importance of the husk covering on the susceptibility of corn hybrids to Fusarium ear rot. Plant Dis. 1996;80(2):208. https://doi.org/10.1 094/PD-80-0208

5. Demissie G, Tefera T, Tadesse A. Importance of husk covering on field infestation of maize by Sitophilus zeamais Motsch (Coleoptera: Curculionidea) at Bako, Western Ethiopia. Afr J Biotechnol. 2008;7(20):377782.

6. Kang MS, Zuber MS. Combining ability for grain moisture, husk moisture, and maturity in maize with yellow and white endosperms. Crop Sci. 1989; 29(3):689-92. https://doi.org/10.2135/cropsci1989.0011183X002900030030x

7. Sweeney PM, Martin SKS, Clucas CP. Indirect inbred selection to reduce grain moisture in maize hybrids. Crop Sci. 1994;34(2):391. https://doi.org/1 0.2135/cropsci1994.0011183X003400020016x.
8. Abadassi J, Hervé Y. Introgression of temperate germplasm to improve an elite tropical maize population. Euphytica. 2000;113:125-33. https://doi.org/1 0.1023/A:1003916928181.

9. Widstrom NW, Butron A, Guo BZ, Wilson DM, Snook ME, Cleveland TE, et al. Control of preharvest afatoxin contamination in maize by pyramiding QTL involved in resistance to ear-feeding insects and invasion by Aspergillus spp. Eur J Agron. 2003;19(4):563-72. https://doi.org/10.1016/51161-0301(03 )00004-2.

10. Wang M, Yan JB, Zhao JR, Song W, Zhang XB, Xiao YN, et al. Genome-wide association study (GWAS) of resistance to head smut in maize. Plant Sci. 2012;196:125-31. https://doi.org/10.1016/j.plantsci.2012.08.004.

11. Cao A, Santiago R, Ramos AJ, Souto XC, Aguin O, Malvar RA, et al. Critical environmental and genotypic factors for Fusarium verticillioides infection, fungal growth and fumonisin contamination in maize grown in northwestern Spain. Int J Food Microbiol. 2014;177:63-71. https://doi.org/1 0.1016/j.ijfoodmicro.2014.02.004.

12. Abadassi J. Maize agronomic traits needed in tropical zone. Int J Sci Environ. 2015;4:371-92.

13. Cui ZH, Luo JH, Qi CY, Ruan YY, Li J, Zhang A, et al. Genome-wide association study (GWAS) reveals the genetic architecture of four husk traits in maize. BMC Genomics. 2016;17(1):946. https://doi.org/10.1186/s12864-016-3229-6.

14. Cui ZH, Xia AA, Zhang A, Luo JH, Yang XH, Zhang $L$, et al. Linkage mapping combined with association analysis reveals QTL and candidate genes for three husk traits in maize. Theor Appl Genet. 2018;131(10):213144. https://doi.org/10.1007/s00122-018-3142-2.

15. Hicks DR, Geadelmann GL, Peterson RH. Drying rates of frosted maturing maize. Agron J. 1976;68(3):452-5. https://doi.org/10.2134/agronj1976.00021 $962006800030004 x$

16. Cavalieri AJ, Smith OS. Grain filling and field drying of a set of maize hybrids released from 1930 to 1982. Crop Sci. 1985;25(5):856-60. https://doi.org/1 0.2135/cropsci1985.0011183X002500050031X.

17. Li SF, Zhang CX, Ming L, Liu WG, Li XH. Research development of kernel dehydration rate in maize. Mo Plant Breed. 2014;12(4):825-9. https://doi. org/10.13271/j.mpb.012.000825.

18. Jiang SQ, Zhang HB, Ni PZ, Yu S, Dong HX, Zhan AG, et al. Genome-wide association study dissects the genetic architecture of maize husk tightness. Front Plant Sci. 2020;11:861. https://doi.org/10.3389/fpls.2020.00861.

19. Zhou GF, Hao DR, Chen GQ, Lu HH, Shi ML, Mao YX, et al. Genome-wide association study of the husk number and weight in maize (Zea mays L.). Euphytica. 2016;210:195-205. https://doi.org/10.1007/s10681-016-1698-y.

20. Matsuoka Y, Vigouroux Y, Goodman MM, Sanchez GJ, Buckler E, Doebley J. A single domestication for maize shown by multilocus microsatellite genotyping. Proc Natl Acad Sci U S A. 2002;99(9):6080-4. https://doi.org/1 0.1073/pnas.052125199.

21. Piperno DR, Ranere AJ, Holst I, Iriarte J, Dickau R. Starch grain and phytolith evidence for early ninth millennium B.P. maize from the central Balsas River valley, Mexico. Proc Natl Acad Sci U S A. 2009;106(13):5019-24. https://doi. org/10.1073/pnas.0812525106.

22. van Heerwaarden J, Doebley J, Briggs WH, Glaubitz JC, Goodman MM, de Jesus Sanchez Gonzalez J, et al. Genetic signals of origin, spread, and introgression in a large sample of maize landraces. Proc Natl Acad Sci U S A. 2011;108(3):1088-92. https://doi.org/10.1073/pnas.1013011108.

23. Lu X, Zhou X, Cao Y, Zhou MX, McNeil D, Liang S, et al. RNA-seq analysis of cold and drought responsive transcriptomes of Zea mays ssp mexicana $\mathrm{L}$. Front Plant Sci. 2017;8:136. https://doi.org/10.3389/fpls.2017.00136.

24. Yi Q, Malvar RA, Álvarez-lglesias L, Ordás B, Revilla P. Dissecting the genetics of cold tolerance in a multiparental maize population. Theor Appl Genet. 2020;133(2):503-16. https://doi.org/10.1007/s00122-019-03482-2.

25. Mano Y, Muraki M, Fujimori M, Takamizo T, Kindiger B. Identification of QTL controlling adventitious root formation during flooding conditions in teosinte (Zea mays ssp. huehuetenangensis) seedlings. Euphytica. 2005;142: 33-42. https://doi.org/10.1007/s10681-005-0449-2.

26. Abiko T, Kotula L, Shiono K, Malik Al, Colmer TD, Nakazono M. Enhanced formation of aerenchyma and induction of a barrier to radial oxygen loss in adventitious roots of Zea nicaraguensis contribute to its waterlogging tolerance as compared with maize (Zea mays ssp. mays). Plant Cell Environ. 2012;35(9):1618-30. https://doi.org/10.1111/j.1365-3040.2012.02513.x.

27. Nzuki I, Katari MS, Bredeson JV, Masumba E, Kapinga F, Salum K, et al. QTL mapping for pest and disease resistance in cassava and coincidence of some QTL with introgression regions derived from Manihot glaziovii. Front Plant Sci. 2017;8:1168. https://doi.org/10.3389/fpls.2017.01168. 
28. Doebley J, Stec AO, Gustus C. Teosinte branched1 and the origin of maize: evidence for epistasis and the evolution of dominance. Genetics. 1995; 141(1):333-46.

29. Tian F, Stevens NM, Buckler ESI IV. Tracking footprints of maize domestication and evidence for a massive selective sweep on chromosome 10. Proc Natl Acad Sci U S A. 2009;106(Suppl 1):9979-86. https://doi.org/10.1 073/pnas.0901122106.

30. Hung HY, Shannon LM, Tian F, Bradbury PJ, Chen C, Flint-Garcia SA, et al. ZmCCT and the genetic basis of day-length adaptation underlying the postdomestication spread of maize. Proc Natl Acad Sci U S A. 2012;109(28): E1913-21. https://doi.org/10.1073/pnas.1203189109.

31. Huang C, Chen QY, Xu GH, Xu DY, Tian JG, Tian F. Identification and fine mapping of quantitative trait loci for the number of vascular bundle in maize stem. J Integr Plant Biol. 2016;58(1):81-90. https://doi.org/10.1111/ jipb.12358.

32. Wang XF, Chen QY, Wu YY, Lemmon ZH, Xu GH, Huang C, et al. Genomewide analysis of transcriptional variability in a large maize-teosinte population. Mol Plant. 2017;11(3):443-59. https://doi.org/10.1016/j.molp.201 7.12.011.

33. Fang H, Fu XY, Wang YB, Xu J, Feng HY, Li WY, et al. Genetic basis of kernel nutritional traits during maize domestication and improvement. Plant J. 2020;101(2):278-92. https://doi.org/10.1111/tpj.14539.

34. Pan QC, Li L, Yang XH, Tong H, Xu ST, Li ZG, et al. Genome-wide recombination dynamics are associated with phenotypic variation in maize. New Phytol. 2016;210(3):1083-94. https://doi.org/10.1111/nph.13810.

35. Sivasakthi K, Thudi M, Tharanya M, Kale SM, Kholová J, Halime MH, et al. Plant vigour QTLs co-map with an earlier reported QTL hotspot for drought tolerance while water saving QTLs map in other regions of the chickpea genome. BMC Plant Biol. 2018;18(1):29. https://doi.org/10.1186/s12870-01 8-1245-1.

36. Han ZM, Hu G, Liu H, Liang FM, Yang L, Zhao H, et al. Bin-based genomewide association analyses improve power and resolution in QTL mapping and identify favorable alleles from multiple parents in a four-way MAGIC rice population. Theor Appl Genet. 2020;133(1):59-71. https://doi.org/10.1 007/s00122-019-03440-y.

37. Cohu CM, Abdel-Ghany SE, Gogolin Reynolds KA, Onofrio AM, Bodecker JR, Kimbrel JA, et al. Copper delivery by the copper chaperone for chloroplast and cytosolic copper/zinc-superoxide dismutases: regulation and unexpected phenotypes in an Arabidopsis mutant. Mol Plant. 2009;2(6): 1336-50. https://doi.org/10.1093/mp/ssp084.

38. Fornara F, Panigrahi KCS, Gissot L, Sauerbrunn N, Rühl M, Jarillo JA, et al. Arabidopsis DOF transcription factors act redundantly to reduce CONSTANS expression and are essential for a photoperiodic flowering response. Dev Cell. 2009;17(1):75-86. https://doi.org/10.1016/j.devcel.2009.06.015.

39. Xu QY, Yin SJ, Ma Y, Song M, Song YJ, Mu SC, et al. Carbon export from leaves is controlled via ubiquitination and phosphorylation of sucrose transporter SUC2. Proc Natl Acad Sci U S A. 2020;117(11):6223-30. https:// doi.org/10.1073/pnas.1912754117.

40. Heuer S, Hansen S, Bantin J, Brettschneider R, Kranz E, Lörz H, et al. The maize MADS box gene ZmMADS3 affects node number and spikelet development and is co-expressed with ZMMADS1 during flower development, in egg cells, and early embryogenesis. Plant Physiol. 2001; 127(1):33-45. https://doi.org/10.1104/pp.127.1.33.

41. Melzer S, Lens F, Gennen J, Vanneste S, Rohde A, Beeckman T. Floweringtime genes modulate meristem determinacy and growth form in Arabidopsis thaliana. Nat Genet. 2008;40(12):1489-92. https://doi.org/10.103 8/ng.253.

42. Schindelman G, Morikami A, Jung J, Baskin TI, Carpita NC, Derbyshire P, et al. COBRA encodes a putative GPI-anchored protein, which is polarly localized and necessary for oriented cell expansion in Arabidopsis. Genes Dev. 2001;15:1115-27. https://doi.org/10.1101/gad.879101.

43. Roudier F, Fernandez AG, Fujita M, Himmelspach R, Borner GHH, Schindelman G, et al. COBRA, an Arabidopsis extracellular glycosylphosphatidyl inositol-anchored protein, specifically controls highly anisotropic expansion through its involvement in cellulose microfibril orientation. Plant Cell. 2005;17(6):1749-63. https://doi.org/10.1105/tpc.105. 031732

44. Tian JG, Wang $C L$, Xia JL, Wu LS, Xu GH, Wu WH, et al. Teosinte ligule allele narrows plant architecture and enhances high-density maize yields. Science. 2019;365(6454):658-64. https://doi.org/10.1126/science.aax5482.
45. Yang N, Xu XW, Wang RR, Peng WL, Cai LC, Song JM, et al. Contributions of Zea mays subspecies mexicana haplotypes to modern maize. Nat Commun. 2017;8(1):1874. https://doi.org/10.1038/s41467-017-02063-5.

46. Knapp SJ, Stroup WW, Ross WM. Exact confidence-intervals for heritability on a progeny mean basis. Crop Sci. 1985;25(1):192-4. https://doi.org/10.213 5/cropsci1985.0011183X002500010046x.

47. Ganal MW, Durstewitz G, Polley A, Berard A, Buckler ES, Charcosset A, et al. A large maize (Zea mays L.) SNP genotyping array: development and germplasm genotyping, and genetic mapping to compare with the B73 reference genome. PLoS One. 2011;6(12):e28334. https://doi.org/10.1371/ journal.pone.0028334

48. Purcell S, Neale B, Todd-Brown K, Thomas L, Ferreira MA, Bender D, et al. PLINK: a tool set for whole-genome association and populationbased linkage analyses. Am J Hum Genet. 2007;81(3):559-75. https://doi.org/10.1 086/519795.

49. de Givry S, Bouchez M, Chabrier P, Milan D, Schiex T. CARHTA GENE: multipopulation integrated genetic and radiation hybrid mapping. Bioinformatics. 2005;21(8):1703-4. https://doi.org/10.1093/bioinformatics/ bti222.

50. Wang S, Basten CJ, Zeng ZB. Windows QTL Cartographer V2.5_011. Raleigh: Dep. Stat. North Carolina State Univ; 2010.

51. Churchill GA, Doerge RW. Empirical threshold values for quantitative trait mapping. Genetics. 1994;138(3):963-71.

52. Lander ES, Botstein D. Mapping mendelian factors underlying quantitative traits using RFLP linkage maps. Genetics. 1989;121(1):185-99.

\section{Publisher's Note}

Springer Nature remains neutral with regard to jurisdictional claims in published maps and institutional affiliations.
Ready to submit your research? Choose BMC and benefit from:

- fast, convenient online submission

- thorough peer review by experienced researchers in your field

- rapid publication on acceptance

- support for research data, including large and complex data types

- gold Open Access which fosters wider collaboration and increased citations

- maximum visibility for your research: over $100 \mathrm{M}$ website views per year

At BMC, research is always in progress.

Learn more biomedcentral.com/submissions 